\title{
Clinical aspects of cardiolaminopathies and prospects for a cardiolaminopathy registry
}

\author{
Sara Benedetti \\ From 1st French-Italian meeting on laminopathies and other nuclear envelope-related diseases \\ Marseille, France. 15-16 January 2015
}

Mutations in the LMNA gene, encoding nuclear proteins lamin $\mathrm{A} / \mathrm{C}$, have been associated with neurological and cardiac disease and a high risk of sudden death. The implant of a cardioverter defibrillator (ICD) is to date the only effective intervention, but no specific guidelines are available. We decided to create a common Italian database integrating clinical and genetic data of patients bearing LMNA gene mutations to improve knowledge of natural history of cardiopathy, define a risk stratification protocol for ICD implant and investigate genotype/phenotype correlations.

To date, 113 patients (age $47 \pm 18$ ) from 11 Italian centers have been included in our database and followed for $7 \pm 11$ years. We evaluated age at onset of different phenotypes. $70 \%$ developed cardiac symptoms, including both rhythm (atrial fibrillation, atrio-ventricular block, ventricular tachycardias) and structural defects (dilated cardiomyopathy, mitral insufficiency), which may or may not be preceded by neurological signs. Cardiac magnetic resonance was pathologic in $2 / 3$ of studied patients. We also evaluated the occurrence of ICD implantation, appropriate shocks, cardiac transplantation and heart failure. Open questions include the identification of predictors of arrhythmias to allow early diagnosis and improve risk stratification and management of asymptomatic patients.

Submit your next manuscript to BioMed Central and take full advantage of:

- Convenient online submission

- Thorough peer review

- No space constraints or color figure charges

- Immediate publication on acceptance

- Inclusion in PubMed, CAS, Scopus and Google Scholar

- Research which is freely available for redistribution

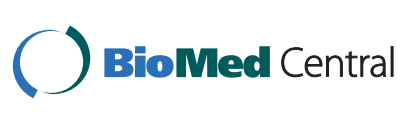

